\title{
Lumen
}

Selected Proceedings from the Canadian Society for Eighteenth-Century Studies

\section{The Quebec Hospitalière and the Closeted Jansenist: The Duplessis-Hecquet Correspondence, with an Unpublished Letter by Hecquet}

\section{Thomas M. Carr}

Volume 29, 2010

URI : https://id.erudit.org/iderudit/1012028ar

DOI : https://doi.org/10.7202/1012028ar

Aller au sommaire du numéro

Éditeur(s)

Canadian Society for Eighteenth-Century Studies / Société canadienne d'étude du dix-huitième siècle

ISSN

1209-3696 (imprimé)

1927-8284 (numérique)

Découvrir la revue

Citer cet article

Carr, T. M. (2010). The Quebec Hospitalière and the Closeted Jansenist: The Duplessis-Hecquet Correspondence, with an Unpublished Letter by Hecquet. Lumen, 29, 91-105. https://doi.org/10.7202/1012028ar

Copyright (C Canadian Society for Eighteenth-Century Studies / Sociéte canadienne d'étude du dix-huitième siècle, 2010
Ce document est protégé par la loi sur le droit d'auteur. L'utilisation des services d'Érudit (y compris la reproduction) est assujettie à sa politique d'utilisation que vous pouvez consulter en ligne.

https://apropos.erudit.org/fr/usagers/politique-dutilisation/ 


\title{
6. The Quebec Hospitalière and the Closeted Jansenist: The Duplessis-Hecquet Correspondence, with an Unpublished Letter by Hecquet ${ }^{1}$
}

\begin{abstract}
Marie-André Duplessis de Sainte-Hélène (1687-1760) is certainly the most versatile and probably the most important Canadian eighteenthcentury woman writer, and her texts are regularly cited by historians of New France. Her Histoire de l'Hôtel-Dieu de Québec, the annals of North-America's first hospital, became the first book published during the lifetime of a woman author from Canada when it was printed in Montauban in $1751 .^{2}$ She was an energetic and capable administrator, elected superior of her house six times, who found time to main-
\end{abstract}

1 My thanks to the Québec Ministère des Relations internationales for partial funding, to the archivists of the Hôtel-Dieu, Sr. Claire Gagnon and François Rousseau, and to Bernard Homassel for their aid.

Publications include Hecquet, Marie Catherine Homassel. "Relation des vexations essuyées au sujet du formulaire; " "Suite comprenant les vexations au sujet de la Constitution Unigenitus." Bibliothèque de Port-Royal, ms. 338bis; Histoire d'une jeune fille sauvage, trouvée dans les bois à l'âge de dix ans. Publiée par Madame H....t. (Paris, 1755); Vie de Madame Michelle Homassel, veuve Fontaine, écrite par Madame Hecquet sa nièce. (Saint-Calais: Imprimerie Peltier, 1862); “Vie de Madame Michelle Homassel, écrite par Marie-Catherine Homassel sa nièce." in Lyon-Caen. 10134; Histoire d'une jeune fille sauvage trouvée dans le bois à l'âge de dix ans publiée par Madame H...t, texte attribué à Ch. M. de La Condamine suivi de documents annexes et présenté par Franck Tinland. Ed. Franck Tinland. (Bordeaux: Éditions Ducros, 1970).

2 Duplessis de Sainte-Hélène, Marie-André. Histoire de l'Hôtel-Dieu de Québec. Ed. Louis-Bertrand de la Tour. (Montauban: Jérôme Légier, 1751). See also Les Annales de l'Hôtel-Dieu de Québec 1636-1716. Ed. Albert Jamet. (Québec: L'Hôtel-Dieu, 1939); reprint, Montmagny, Ateliers Marquis, 1984 ; “Lettres." Ed. A.-L. Leymarie. Nova Francia 2-6 (1926-1931). 
tain multiple correspondences. Her letters to her childhood friend, Marie-Catherine Homassel Hecquet (1686-1764), along with some of her business correspondence, were published in the late 1920s in Nova Francia by A.-L. Leymarie. She also wrote numerous occasional pieces on spiritual topics, most of which remain unpublished ${ }^{3}$. Hecquet spent a good part of her life in Abbeville in Picardy where she was born and raised six children, although she moved to Paris to be near married daughters late in life. Although she seemed to have had a fine head for business, it is not known what role she played in the family manufacturing enterprise specializing in woolen velvet fabric. Her only work published during her lifetime was the 1755 Histoire d'une jeune fille sauvage trouvée dans les bois à l'âge de dix ans publiée par Madame H....t. This book recounts the story of a feral girl found by peasants in the woods near Châlons-en-Champagne in 1731. However, she also wrote compulsively about her spiritual life and her attachment to Jansenism. Her biography of the aunt who raised her in Paris after her mother's death, the Vie de Madame Michelle Homassel, veuve Fontaine, écrite par Madame Hecquet sa nièce, was published in 1862. Neither scholars who have studied the Histoire d'une fille sauvage nor those who have used Duplessis' correspondence with Hecquet have developed the implications of her Jansenism. The term "closet" is used here loosely in three contexts: this reticence in pursuing Hecquet's Jansenism by scholars, whether because of ideological blinders or lack of knowledge of her personal texts; her "outing" by her bishop; her apparent silence about her stance in her letters to Marie-André.

Since the subject of this article is the Duplessis-Hecquet correspondence, the missed opportunities in regard to the Histoire will only be sketched out. None of the major commentaries on that book completely accept the attribution to Hecquet, ${ }^{4}$ and thus they fail to explore its potential Jansenist orientation. Franck Tinland, who published the only modern edition in 1970, did question the often accepted attribu-

3 See Thomas M. Carr, Jr. "Writing the Convent in New France: The Colonialist Rhetoric of Canadian Nuns." Quebec Studies 47 (2009): 3-23 for a discussion of her writing in relation to that of other Canadian nuns.

4 The notable exception is Franck Rolin who documented Hecquet's relation to the feral girl with exhaustive archival research. However, his findings have had limited impact because his privately printed book has not found its way into many libraries or been reviewed. See Franck Rolin, Marie-Angélique: Haut Mississippi, 1712-Paris-1775: survie et résurrection d'une enfant perdu dix années en forêt. (Charenton-Le-Pont: Terre Éditions, 2004). 
tion of the book to the geographer Charles-Marie de La Condamine, ${ }^{5}$ but maintains it in the second edition of L'Homme sauvage, where he describes it as "un petit mémoire composé en 1755, vraisemblablement par Ch.-M. de La Condamine, mais signé du nom de Madame H...".6 Julia V. Douthwaite, in her 2002 The Wild Child, Natural Man and the Monster, where the Histoire is given a sympathetic reading, remains very tentative, speaking of a "certain Mme $\mathrm{H}-\ldots$ " and saying that La Condamine evokes "a fiction of female community" between Mme Hecquet and wild girl. If Tinland or Douthwaithe had pursued the allusion to Hecquet's correspondence with her nun friend, which had been published in Nova Francia, they would have found clear confirmation of Madame Hecquet's hand in the book. In the Histoire, Hecquet devoted ten pages $(1755,59-68)$ describing dolls representing various Amerindian tribes and quoted at length a letter of October 30, 1751 sent to her by Duplessis whom she called "mon intime amie" $(1755,59-60)$ as proof of her contention that the wild girl was an Innuit. ${ }^{8}$ In an October 30, 1753 letter Duplessis acknowledged receipt of "la relation que vous m'avez envoyée des aventures de Mlle de Blanc," a text that must have been an early version of the Histoire. ${ }^{9}$ In an October 25, 1755 letter, Duplessis told Hecquet that she had seen a copy of the book; she reaffirmed the accuracy of all the information she had given. Thus, if commentators on the Histoire had consulted the published correspondence, they would have found not only this proof of Hecquet's maternity of the Histoire, but also have been led to her Jansenist writings conserved in the same cartons in the Archives Nationales that contain the manuscripts of Duplessis' letters.

5 Charles-Marie de La Condamine, "Lettre à M. de Boissy, " Mercure de France, April 1755: 74-75. Tinland, 41-42. Franck Tinland, L'Homme sauvage: Homo ferus et Homo sylvestris de l'animal à l'homme. $2^{\text {nd }}$ ed. (Paris: L'Harmattan, 2003).

6 L'Homme sauvage, 69.

7 Julia V. Douthwaite, The Wild Child, Natural Man and the Monster: Dangerous Experiments in the Age of Enlightenment. (Chicago: U of Chicago P, 2002) 41. Douthwaite (234n) refers to La Condamine's April 1755 letter to the Mercure de France in which he declares he edited the manuscript of a woman whose biographical details correspond to those of Hecquet (74).

8 Duplessis, François-Xavier. Lettres du P. F.-X. Duplessis de la Compagnie de Jésus. Ed. J.-Edmond Roy. (Lévis: Mercier et Cie, 1892).

9 Spelling and punctuation have been modernized within the article. Letters are quoted from the Leymarie edition, except the one published for the first time in the appendix. 
Commentators on Duplessis have not followed up on Hecquet's Jansenism either. Sister Mary Loretto Gies, whose 1949 Laval doctoral dissertation remains the most detailed overall study of Duplessis, was aware of Hecquet's Jansenist ties and published an extract of a Jansenist profession of faith by Hecquet as an appendix of her thesis. ${ }^{10}$ This text comes from a 1732 spiritual testament recounting Hecquet's refusal to accept the papal constitution of 1713 Unigenitus which condemned Pascal Quesnel, a disciple of Cornelius Jansen and Antoine Arnauld and which defined battle lines between Jansenists and Ultramontanes in eighteenth-century France. Geis called Duplessis' tie to a Jansenist "ahurissante" (231) and might well have been content not to explore the full extent of Hecquet's Jansenism. The fact that a favorite daughter of the Canadian church could have corresponded for forty-years with an unrepentant Jansenist was inconvenient in the years before Quebec's Quiet Revolution. "Comment peut-on concilier cette liaison entre une religieuse canadienne et une famille d'appelants forcenés?" (232) asked Geis. Did Duplessis even know? she wondered. She cites a letter by the French-born archivist Claude de Bonnault, who sent her the Jansenist manifesto and who thought that Duplessis probably knew, but showed "une indulgence digne de remarque" about the matter (232). Even scholars such as François Melançon and Paul-André Dubois, who were unlikely to have been blinded by Ultramontane prejudice, as Geis might have been, did not delve into the Jansenist connection. ${ }^{11}$

The irony is that such ideological blinders prevented scholars from learning more about Duplessis' youth. Little was known about Duplessis' childhood other than her date of birth in 1687, reportedly in Paris, and the fact that, when her parents emigrated to Canada, they left her in the care of her maternal grandmother until 1702, when her mother returned to France to bring her daughter to Canada. Some further information can be gleaned from her letters, for example, that her grandmother had a home in Chevreuse, but there is a tendency to embroider the few known facts. The Dictionary of Canadian Biography states that Duplessis was educated in the boarding school of the Filles de la Croix in

10 Gies, Mary Loreto. "Mère Duplessis de Sainte-Hélène, annaliste et épistolaire." (Ph.D. dissertation. Laval 1949). Gies speaks of "des recherches faites dernièrement aux Archives de Paris" (231), suggesting that she did not examine the carton personally.

11 François Melançon and Paul-André Dubois, "Les Amitiés féminines et la construction de l'espace savant du XVIII e siècle." Érudition et passions dans les écritures intimes. Ed. Manon Brunet. (Montreal: Éditions Nota Bene, 1999) 97-113. 
Paris without citing a source, although she only says herself in a letter of October 10, 1747 that her grandmother found comfortable lodging there.

The letters supply no information about how she met Hecquet, but the young Duplessis does appear in Hecquet's biography of Michelle Fontaine, the aunt who raised her. Marie-André and Marie-Catherine quickly became inseparable when they met in late 1691 through two aunts who were friends and later business associates $(2008,114)$. Hecquet's aunt became a sort of junior partner in the dressmaking shop of Duplessis' aunt, Anne-Marie Leroy. Leroy must have recognized the administrative talents that her niece would later show since there was talk of her eventually taking over the business $(2008,124)$. Duplessis' grandmother allowed her to spend long periods in Leroy's household so the girls could be together. However, the two aunts quarreled, and when Duplessis' mother arrived in France to visit family in 1702, she decided to return precipitously to Canada taking her fifteen year old daughter with her $(2008,127)$.

Hecquet's narrative is built on the contrast between her own aunt's unaffected, deep piety and the exaggerated devotion of Duplessis' aunt. Both aunts moved in devout circles that featured an austere piety accompanied by study that was similar to that practiced by Jansenists. The aunts shared the same Oratorian confessor, Jean Soanen (16471740), who was occasionally accused of Jansenism because of his rigorism, despite being a successful court preacher. Only later would Soanen take an explicit Jansenist stand when, as bishop of Senez, he became one of the fiercest opponents of Unigenitus. In 1727, Soanen would be relieved of his episcopal functions for promoting an appeal to a general council against the pope.

In her Relation des vexations au sujet $d u$ formulaire, Hecquet declares that it was only when she was accused of being Jansenist at age twentyone that she came to realized that she was one (105). In a scenario that somewhat reverses the trajectory of Diderot's nun Suzanne Simonin, her father in 1699 forced her to leave her aunt's care in Paris and return to Abbeville to marry in order to keep his business in the family, despite her desire to pursue a religious vocation. However, she was able to enter the Parisian monastery of Liesse around 1704 to test her calling (103). Three years later, her father used his connections with the bishop of Amiens to pry her out of Liesse, complaining to the bishop of the convent's supposed Jansenist orientation. The prelate, Pierre de Sabatier (1654-1733), had her removed and interrogated her at length. She maintained to him at this time that she had never been exposed to Jansenist theology or to quarrels over the formulary, either by Madame Fontaine, Soanen or the nuns of Liesse. Under great pressure and deprived of advisors she could trust, she signed the formulary against Jansenism 
(152), although she immediately regretted her act. After three more years at her father's, she agreed to marry a cousin, Jacques Hecquet in order, as she says, to "me mettre à couvert de ses [the bishop's] persécutions" (Suite 208). In short order found herself a mother and head of a large household. Her "outing" was chiefly a self-revelatory experience that changed her relation with others very little. Sabatier was not satisfied with her signature, and his clergy continued keeping their eye on her. For her father, the accusation of Jansenism had only been a pretext to reclaim her from Liesse, and he was happy to insist that she remain at home rather than be imprisoned in a conformist convent as the bishop threatened. For her part, she began educating herself in Jansenist literature, starting with book defending Augustine that she found in her father's library (Relation 177) and going on to Quesnel's Réflexions morales which she read with her husband. When her husband surrendered the book during her absence to their pastor at his demand in 1714, she bought a new copy (Suite 209); in 1722, her confessor refused her absolution because she would not turn it over to him (Suite 212). She pursued this strategy much of her life: while not seeking to provoke confrontations, she stood her ground energetically when attacked.

Just when the two childhood friends began exchanging annual letters is not clear, although it seems to have been during this period between 1714 and 1722 . The first extant letter dates from 1718, about 18 years after they last saw each other when Hecquet returned to Abbeville. Thirty-three of Duplessis' letters to Hecquet have survived because Hecquet saved them preciously, and they eventually passed into public hands when the family papers of a granddaughter of Hecquet were confiscated during the Revolution. Little of Hecquet's side of the correspondence seems to have been preserved. She herself saved drafts of two letters (1740 and 1751) that are included with Duplessis' in the Archives Nationales holdings. The Hôtel-Dieu's archives hold a single letter from Hecquet, one written in response to Duplessis' description in 1755 of the fire that destroyed the hospital. It is published here for the first time as an appendix. Whether Duplessis, or later Hôtel-Dieu archivists discarded Hecquet's other letters is not known. In any event, the letters were not treated with the reverence accorded to the ones that Duplessis' Jesuit brother François-Xavier (1694-1771) sent his sister from France which have been carefully preserved and published.

Despite the value Hecquet obviously placed on her correspondence with Duplessis, she appears to have held back on one essential point: there is no indication that she ever revealed her ardent Jansenism. In fact, all indications point to her trying to hide it. Thus, given what we now know about Hecquet's stance, Geis's question how Duplessis could have corresponded with an unrepentant Jansenist must be 
reversed. What were the implications for Hecquet of corresponding with the sister of a Jesuit who cultivated quarrels with Jansenists? Neither Hecquet nor her immediate family was Jansenist during the years they knew each other in Paris, and it is unlikely that Hecquet would have revealed her stance when the correspondence began around 1718 . At the most, she might have included the kind of brooding meditations on the fallen state of France that we find in her drafts. These laments could have been penned by many Christians of the day, and Duplessis, who was of a much more optimistic and less tormented bent, was perfectly capable of replying in kind about the corrupt state of Canada. In fact, in her second extant letter to Hecquet (October 21, 1720), after noting that her brother was "dans la Compagnie de Jésus, fervent comme un ange" and teaching in a Jesuit college in Vannes, she declares with satisfaction that Jansenism was the only ill Canada was free of: "Il n'y a que cette misère, je veux dire l'erreur, qui n'afflige pas le Canada. Nous participons à toutes les autres dont la France est accablée." Just prior to this statement, she had mocked appellant nuns in Hecquet's hometown of Abbeville: "Je ne pus m'empêcher de rire quand je vis dès l'an passé sur la liste des appelants au futur concile les soeurs Cordelières d'Abbeville. Il me semble qu'il ne convient guère à des filles d'entrer dans ces sortes d'affaires et qu'il faut qu'un parti se sente bien faible quand il accepte et qu'il recherche de tels appuis."

Given such sarcasm, it is not surprising that Hecquet appears to have done all she could to avoid letting Duplessis know her stand against Unigenitus. On November 9, 1751, Duplessis complains that Hecquet would not reveal her Parisian address and said their correspondence could be facilitated if Hecquet would only send her letters care of the Jesuits at their college Louis-le-Grand. If Duplessis ever learned the truth about her appelante correspondent, it was probably not directly from Hecquet, but from friends who dined with Hecquet in the Parisian home of one of her daughters in the 1753 or 1754, or from inquiries her brother might have made though his extensive contacts.

Although we have little of Hecquet's side of the correspondence, her self-censoring can be inferred from comparing Duplessis' letters with Hecquet's accounts of her persecutions. Duplessis' younger brother François-Xavier, who left Canada in 1716 to become a Jesuit in France, lived up to his given name by becoming a famous missionary preacher throughout France. These missions, revival-like campaigns of sermons, confessions, and religious instruction ${ }^{12}$, were meant to win back a pop- 
ulation that was increasingly dechristianized. He bragged in letters to his sister back in Quebec of the throngs who received communion after his sermons: 22,000 in Amiens in 1735 (181); 13,000 in Douay (178). The Jansenists were skeptical of such mass conversions and ridiculed the Jesuit as a gesticulating windbag. Le Père Duplessis was more than happy to reply in kind.

When the nun learned that her brother was to preach in Amiens in 1735, she asked Hecquet to have her son Philippe, who lived there, contact the Jesuit. "J'apprends que mon frère le père Duplessis y va faire des missions. Je vous prie d'informer Mr votre fils de l'étroite liaison qui est entre nous, afin qu'il fasse connaissance avec mon frère dont on nous écrit beaucoup de bien. C'est un homme plein de zèle dont Dieu bénit les travaux abondamment." If Hecquet reported such an encounter between Philippe and François-Xavier in her own response, there is no sign of it in Duplessis's 1736 letter. In October 1736, the Jesuit preached in Hecquet's own hometown of Abbeville. In her letter of the next year, Duplessis was clearly miffed that Hecquet did not report having attended the mission or taken the opportunity to meet the nun's brother:

Quelques personnes me mandent qu'on a fait une mission à Abbeville où le père Duplessis mon frère a été avec Mr. l'évêque d'Amiens. J'ai de la peine à le croire parce que vous ne m'en dites rien, et qu'il me semble, ma chère amie, que si cela était, vous êtes trop chrétienne pour n'y avoir point pris de part, et trop honnête pour ne m'en avoir rien écrit. Cependant je ne vous en ferais pas un crime.... On nous mande des merveilles de ce cher frère. C'est un homme tout rempli de Dieu qui ne respire que le salut des âmes, et dont le ciel bénit les travaux admirablement.

Hecquet's Suite des vexations tells a very different story. She was conveniently in Paris where her husband was ill during the mission. But she instructed her household servants that, while they could attend the sermons, they should only make their confessions to local priests, whom she did not suspect of offering the easy absolution of the Jesuits (255). Some of her employees, who shared her distaste for the preacher, were none too discreet and labeled him the "Arlequin du bon Dieu" (258). Since she was spied upon as a known Jansenist, word got back to the bishop of Amiens, and she was compelled to undergo a long inter-

13 For examples of such polemics, see the Jansenist journal Nouvelles Ecclésiastiques, (25 June 1729); (1731): 222; (1736): 109, 111; (1737): 190; (1748): 14, 60. 
rogation by her pastor. In her narrative, she recounted the point and counterpoint of the examination in great detail, proud of her debating skills (259-78). In her eyes, she won at least a tactical victory since the pastor agreed not to deprive her of communion (278). Still, there is a curious bit of self-censorship in her own account of the affair; Hecquet did not mention that the Jesuit preacher was the brother of her childhood friend. She introduced him in her narrative only as "un natif de Québec en Canada, nommé le Père Duplessis" (254).

Two features undercut the poignancy of her stance. First, a measure of equivocation underlies her confrontations with authorities. For example, in her 1707 interrogation by the bishop of Amiens, she declared that she did not recognize portraits of Antoine Arnauld (121), thus suggesting that she was not familiar with leaders of the Jansenist party. Yet further in her account of the meeting, it becomes clear that she did know of Jansenist leaders such as Arnauld, Saint-Cyran, Nicole, when she replied to an attack against them by the bishop with, "Que dois-je penser de tous ceux qui m'ont parlé autrement en leur faveur" (123)? Moreover, although she professed never to have heard of the debates over the formulary, she managed to defend a position very like the distinction the Jansenist theologians made between le droit et le fait, when she first refused to sign because she was not sure the condemned propositions were in Jansen's book. No wonder the bishop was suspicious of her claims of ignorance. Second, even if she did not seek out confrontation, she clearly relished exercising her ability to defend her position vigorously and at length. Her writings contain many accounts of such debates with church officials, and she clearly saw herself as continuing the tradition of the nuns of Port-Royal who consigned transcripts of their interrogations in their captivity accounts. As a Jansenist who believed that she was faithful to the key teachings of the church, all the while being told by that church that she was a heretic and a rebel, she had learned to use equivocation and concealment to continue participating in the sacraments. She lived a compartmentalized life, telling church authorities only as much as she had to. She seems to have used the same strategy with her girlhood friend.

Hecquet's reticence with Duplessis explains important aspects of the correspondence. Her two drafts and one complete letter all contain laments on the refusal of the French to remain faithful to the Gospel, for example, "notre ingratitude et notre rébellion aux lois de ce saint Évangile" (1740 draft). In her eyes, chief among the offenders was the French hierarchy that departed from the true theology of grace by enforcing Unigenitus. But unwilling to express this explicitly to Duplessis, she takes aim at a common enemy, the unbelief of philosophes, atheists, and deists (1751 draft, 1756 letter). At the same time, Hecquet's Jansen- 
ism also shaped Duplessis' letters. Jansenist exegesis postulated that the apostasy the Christians of France displayed in complying with Unigenitus would be compensated for by the conversion of the Jews and pagans. Hence Hecquet's intense interest in the Amerindians. From the beginning of the correspondence, Duplessis' letters contain report after report on native peoples, with a special eye toward the success of missionaries $(1718,1723,1739,1751,1756)$, reports that Hecquet requested repeatedly. Hecquet comes the closest to expressing her belief in her 1756 letter, where she inquires "si notre sainte religion fait quelques progrès parmi ces pauvres idolâtres que j'aime, parce que j'espère que leur conversion plus ou moins prochaine, mais néanmoins certaine selon la parole de Dieu, consolera notre sainte mère l'Église de tous les mauvais chrétiens qui l'affligent à présent." This belief that the conversion of the pagans presages the return of French Catholics to orthodoxy also explains her interest in the feral girl, whose conversion she recounts in her 1755 Histoire d'une fille sauvage.

The correspondence had very different meanings for each woman. For Duplessis, born and raised in Paris, but living in a community in Quebec whose other members were Canadians, the letters to her girlhood friend linked her to the land of her birth. Hecquet was one of many correspondents in France. She did not hesitate to ask her for the kind of favors she requested of other correspondents: Hecquet obligingly sent cloth, books, and reading glasses. For her part, Hecquet never seems to have disclosed to her friend what was most meaningful in her life. She chose to reveal this intimate self in her accounts of her persecutions, her biography of her aunt, and her letters to her children. These texts were meant for her immediate family, although some, such as her aunt's biography, circulated in manuscript in Jansenist circles. Her correspondence with a mother superior, whose brother was a Jesuit, was perhaps a way for her to affirm what she always insisted upon in her declarations of faith: even though she rejected Unigenitus, she accepted all the essential truths taught by the church's ancient creeds. ${ }^{14}$ Hecquet must have found confirmation of her catholicity in remarks such as these by Duplessis: “Une des choses qui m'attache le plus à vous [est] de penser que vous êtes véritablement chrétienne" (October 13,1731) or "Tenons

14 Her 1732 profession of faith begins, “ Je proteste que je suis née, que j'ai vécu, et que je veux mourir dans le sien de l'Église catholique, apostolique et romaine, que je crois tout ce qu'elle croit, que je suis soumise à ses décisions et à ce qu'elle ordonne, et que je condamne et anathématise toutes les erreurs et sentiments qui pourraient m'éloigner de sa foi et de sa discipline" (Arch. nat. T 77, p. 1) 
ferme à la colonne de la foi, et souvenons-nous que celui qui persévéra jusqu'à la fin sera sauvé" (October 25, 1755).

The republication in 2008 by Nicolas Lyon-Caen of Hecquet's life of her aunt has "outed" her Jansenism in the scholarly community such that it can no longer be ignored. ${ }^{15}$ If commentators on the Histoire had pursued her citation of a letter of her nun friend, they would have found evidence of these ties in the introduction to Duplessis' correspondence published in the late 1920s. Likewise, commentators of Duplessis have failed to follow up on the Jansenist affiliation of Duplessis' friend, thereby missing information about the nun's youth. One might say a failure to take convent writing seriously in the first case and Ultramontane prejudice in the second. Acknowledgement of the strategy of concealment that Hecquet used in her letters reveals an unsuspected complexity to the correspondence. Her own letters turn on a subtext she hid from her friend. To maintain the flow of letters Hecquet avoided the one subject that engaged her the most, but she compensated for this silence by stimulating Duplessis' accounts of Amerindian life. These in turn sparked Hecquet's interest in the feral girl and led to the publication of her Histoire d'une jeune fille sauvage. Thus, despite their doctrinal differences and the fact that each wrote for quite different reasons - Marie-André to promote the interests of her monastic community and Marie-Catherine to justify her Jansenist stand - the writing of each of these prolific women was inflected by the stance of her childhood friend.

THOMAS M. CARR, JR.

University of Nebraska-Lincoln

\section{An Unpublished 1756 letter by Hequet held in Archives of Hôtel-Dieu of Québec}

Space considerations do not permit annotating this letter, which seems to have been written in spring 1756 in response to Duplessis' letter of October 25, 1755 describing the June $7^{\text {th }}$ fire that destroyed the hospital. Duplessis replied on November 8, 1756. Readers have only to con-

15 Nicolas Lyon-Caen, Un Roman bourgeois sous Louis XIV: Récits de vies marchandes et mobilité sociale: les itinéraires des Homassel. (Limoges: PULIM, 2008). 
sult the notes for these letters published by Leymarie in Nova Francia 4 (1929) 55-58, 110-114 to understand the allusions. The letter is also interesting for its Jansenist interpretation of the Lisbon earthquake of 1755. In keeping with the principles of Leymarie's edition, the spelling and punctuation have not been modernized.

\section{Madame et tres chere Amie}

Je ne peut assez vous marquer quelle est ma reconnoissance de ce que malgré une Espece de Silence qu'une amitié moins affermie que la votre, auroit put attribuer à toute autre cause que des infirmites reelles, vous ayez Continué de me rendre justice, et de ne point douter de la Mienne. Ecoutez la donc toujours Ma chere amie, Cette precieuse amitié pour moy; Et Elle vous persuadera de plus, en plus quil ne peut y avoir que le frequent derangement de ma Santé qui puisse m'empecher de vous Ecrire au tems marqué pour le depart des vaisseaux; et me restraindre a vous donner quelques signes de vie par les Correspondances de mon Gendre, le Sr Bourdeaux. Jay donc receu votre chere Lettre avec double action de graces. Mais Quoi! Ne gouteray-je donc jamais aucun plaisir sans amertume ? Celui que j'Epprouvay alors, puisqu'avant l'avoir ouverte sa vue seule m'apprenoit que vous viviez et m'aimiez toujours, fut bientôt troublé par la peinture que vous y faite du danger personnel que vous et Madame votre sœur avez Couru dans l'accident arrivé a votre $S^{\text {te }}$ Maison. Ses suites sont des plus tristes, J'En conviens, Mais dans un malheur si peu prevu et si subit, n'est-ce pas un grand sujet de Consolation lorsque ceux et celles qui peuvent le reparer, En sont Echappez? Telles Estes vous Ma chere amie Et les autres Dames que dieu a retirez d'un si violent incendie. Vous Etes les pierres vivantes que sa providence a reservez pour conserver et transmettre a celles qui vous succéderons dans une Nouvelle maison terrestre, l'Esprit d'humilité et de charité qui ont étez les premiers fondement de l'ancienne.

Mais Ma chere Amie, Quelles reflexions n'ont pas suivies l'impression qu'a fait sur mon Esprit, la nouvelle de votre destruction? Le sort de Lisbonne et des autres villes du Portugal, d'Espagne et autres parties de l'Europe la france Comprises Et d'une partie de l'affrique; toujours present a mes yeux pour les Lettres journalières qui n'ont cessai jusqu'a ce jour de nous en apprendre de nouvelles suites. Leur funeste sort, dis-je avoit deja rempli mon Esprit de terreur voiant qu'il portoit toutes les marques de la plus grande Colere de Dieu; Car en Effet, tous les Elemens : le Ciel par ses vents et ses orages, la terre par ses mouvemens et les ouvertures de ses abimes, Le feu par ses embrassemens souterrains, la mer et les rivieres par leurs inondations : tous comme 
pour se venger de l'abus que les hommes en font, se sont reunis pour abimer sans ressource la pluspart de ces malheureux païs et rendre le reste inhabitable. Dieu me garde de croire que les habitans eussent Etez Cependant les plus Coupables de tous les hommes. Ce que dit J. C. au suiet des Galileens massacrez par Pilate et des Juifs Ecrasez sous la tour de Siloé, me condamneroit. Mais dans la Confiance que Dieu avoit des Elus dans ce peuple innombrable qui a peri En tous ces lieux, j'ay pensé, quil falloit croire que Dieu Etoit bien irrité, puisquil Etendoit ses fleaux indistinctement sur les bons et sur les mauvais. Cest ce qui m'a touchée a votre suiet, Ma chere amie, mais non surprise; Car l'Ecriture $S^{\text {te }}$ nous apprend: Que Dieu a souvent permis, pour punir les pechez de son peuple, que son tabernacle et son temple de Jerusalem fussent renversez et detruits par ses Ennemis; Et qu'Enfin ce meme Temple, et Jerusalem Elle meme fussent reduits en Cendres, Et tout ce peuple chaste et Exilé de sa patrie jusqu'à nos jours, quoique plusieurs Prophetes et grand nombre de Justes, l'habitassent lors de ces Evenemens et dussent estre Enveloppez dans le malheur General.

Mais apres tout, Ma chere Amie, Cette corruption du Coeur de l'homme que Dieu punit souvent par ses fleaux temporels n'est elle pas aussi Generale? Vous en Gemiste en votre Lettre, et vous avez raison; mais j'ose dire avec plus de raison que vous ne croiez vous-meme; Car on peut dire sans Exageration que depuis la tete jusqu'aux pieds, toute chair est corrompue aux yeux de Dieu. Le peu que vous me dittes sur notre commune Patrie me fait apercevoir que vous savez quelque chose des maux dont elle est acablée. Ce n'est rien Ma chere amie d'entendre en parler dans des païs Eloignez; mais cest tout de voir sur les lieux par soimeme. Cette Patrie, autrefois le fidel Echo par lequel l'Eglise Notre $\mathrm{S}^{\text {te }}$ Mere faisoit Entendre sa voix, non seulement a ceux de ses Enfans qui y habitoient, mais encor a ceux d'Entre eux qui la consultoit de toutes les autres parties du monde. Cette Patrie, autrefois le soutien et le refuge de la Religion persecutée soit en son chef soit en ses membres. Cette Patrie Enfin, ou le flambeau de la foy a brillé le plutot et le plus longtems: a merité par son Orgueil et par son ingratitude, d'estre Enfin abandonnée, Ainsi que nous la voions aux Tenebres, a l'Ignorance, a des Erreurs sans nombre, Et la plus affreuse corruption des moeurs. Non, je le repette, La langue ni la plume ne peuvent seulement crayonner ce que les yeux et les oreilles voient et Entendent. Mais ce qui Etonne le plus, C'est de voir l'aveuglement ou plutot l'Endurcissement des pretendus Scavans et Esprits forts d'entre nos Compatriotes. Insensibles aux outrages faits a Dieu et aveugles sur les maux qui affligent l'Eglise, ils sont fort Eloignez de penser que tous les fléaux qui ont commencez d'abimer une partie de L'Europe, Et qui menacent encor le reste, soit des marques de la Colere de Dieu. Non ils ny pensent pas; 
ou s'ils y pensent, ce n'est que pour s'Eforcer d'Empecher les autres d'y penser avec quelque fruit. Toute leur attention est fixée et leurs Etudes se bornent a prouver pour rassurer le peuple Efrayé, Que tout ce bouleversement de la Nature que nous venons de voir sur la terre et sur la mer, n'est qu'un Efet tout naturel de la Compression du soleil sur ces parties. Insensez quils sont, ne pourroit on pas leur demander: $\mathrm{Si}$ ce soleil a qui uniquement ils attribuent tant de funestes Evenemens, ne passe pas actuellement sur ces memes parties, Et pourquoi donc la meme compression et les memes malheurs n'arrivent ils pas tous les ans? Pourquoi, les memes malheurs sont ils arrivez en meme tems En diferends Royaumes et Climats, sur lesquels naturellement le soleil ne pouvoit comprimer en meme tems? Cest disent-ils, par la compression naturelle des premieres parties Comprimées. $\mathrm{O}$ La belle raison! dès la, le Deluge ni la pluie de feu sur Sodome, ne sont plus des effets de la Colere de Dieu. Ce sont des Efets tout naturels de la force du Soleil qui aura comprimé, par Maladresse sans doute, les abimes d'eau reservées dans la terre et dans les nuées, Et qui par la a causé le Deluge. Ce sera encor luy qui, par la meme raison, aura comprimez les matières inflammables contenues dans les nuées, lesquelles Embrassés par sa chaleur trop proche d'Elles se seront precipitez sur Sodome.

Voila Ma cher amie ce que nous sommes reduits d'Entendre sur ces funestes Evenemens, de la part des Scavans du Siecle, Esprits forts, Libertins, athée, Deistes etc qui font a present les $7 / 8$ de nos compatriotes. personne ou presque personne par comparaision a la multitude de ces premiers, ne voit la main de la justice de Dieu dans les mouvemens Extraordinaires des causes secondes ou naturelles, par lesquels il a voulu nous montrer comme une Esquisse du Jugement dernier, avant de nous faire subir le notre particulier; Et par consequent, personne ne sy prepare Et ne quitte sa premiere voie. Chacun continue Gaiement son chemin. Je m'imagine causer avec vous Ma chere Amie. pardonnez moy si ie le fais longtems. Cest pour les deux precedentes années et pour celle qui les suit.

Apres une Longue absence que les infirmitez de $\mathrm{Mr}$ hecquet ont Causée, Une nouvelle dont il a Eté attaqué, a aussi donné lieu a son retour icy depuis quelques mois. Un atteinte d'apoplexie degenerée en paralisie ou affoiblissement de tout le Coté droit, a demandé toute mon attention et tous mes Soins, Et par consequent sa residence aupres de moy. Je les Emploie autant que ie peut a son soulagement Et a sa consolation, car son Etat l'aflige, Sinon par moy meme Etant de ma part fort usée et infirme, mais au moins par le moien des domestiques que jay mis aupres de luy Je le recommande a vos prieres Et celles de votre $\mathrm{S}^{\text {te }}$ Communauté! Et de my pas oublier en ayant plus besoin que personne. 
Comme je ne sort presque plus que pour aller a la paroisse qui est a quatre pas du Logis; jay prié Le $S^{r}$ Bourdeau Mon Gendre de faire pour moy l'Emplette des Lunettes qui vous manquent, Et lui ay marqué les ages que vous indiquez. Je souhaite quelles vous conviennent depuis la premiere jusqu'à la derniere; cest a dire que vous les puissiez user toutes l'une apres l'autre; Mais a condition que vous en Emploierez l'Essay premierement a m'apprendre les Causes de votre incendie si vous les avez scut; car pour moy, ie le Confesse, mon premier regard, tant pour le votre que pour celui de Montreal que le Gazette nous a aprit, a Eté du coté des Ennemis de l'Eglise et de notre Nation, je veux dire des Anglais vos voisins. Ce n'est qu'une pensée au moins; Et non pas un jugement, ainsi ne $\mathrm{m}^{\prime}$ En faite pas un scrupule. ${ }^{\mathrm{e}}$ Quels sont a present, Entre les Sauvages, nous cousins et bons amis; Et pourquoi ils ont levez la hache contre les anglais autrefois leurs bons amis. $3^{\mathrm{e}}$ Enfin $\mathrm{Si}$ notre $\mathrm{S}^{\text {te }}$ religion fait quelque progrez parmi ces pauvres Idolatres que j'aime parce que j'espere que leur conversion plus ou moins prochaine, mais neanmoins certaine selon la parole de Dieu, consolera notre $S^{\text {te }}$ mere $l^{\prime} E g l i s e$, de tous les mauvais chretiens qui l'afligent a present.

$\mathrm{Mr}$ hecquet prend la Liberté de vous presenter ses tres humbles civilitez et a $\mathrm{M}^{\text {de }}$ votre Sœur. Je $\mathrm{m}^{\prime} \mathrm{y}$ joint tres intimement et vous prie destre toujours bien persuadée que ie seroy toute ma vie avec la meme tendresse et le meme respect

Madame Et tres chere amie

Votre tres humble et obeissante Servante

$\mathrm{M}$ h. homassel, hecquet de Villers 